\title{
The Influence of Patient Positioning in Breast CT on Breast Tissue Coverage and Patient Comfort
}

\section{Der Einfluss der Patientenlagerung in der Brust-CT auf die Brustgewebeabdeckung und den Patientenkomfort}

Authors

Affiliations
A. C. Rößler ${ }^{1}$, E. Wenkel ${ }^{2}$, F. Althoff ${ }^{1}$, W. Kalender ${ }^{1}$

Institute of Medical Physics, University of Erlangen

2 Radiological Institute, University Hospital of Erlangen
Key words

- breast

- $\mathrm{CT}$

- MR imaging

received $\quad 12.3 .2014$

accepted $\quad 25.8 .2014$

Bibliography

Dol http://dx.doi.org/ 10.1055/s-0034-1385208

Published online: 22.9.2014

Fortschr Röntgenstr 2015; 187:

115-122 @ Georg Thieme

Verlag KG Stuttgart · New York . ISSN 1438-9029

\section{Correspondence}

\section{Ann-Christin Rößler}

Institute of Medical Physics,

University of Erlangen

Henkestraße 91

91052 Erlangen

Germany

Tel.: ++ 49/9131/8525559

Fax: ++ 49/9131/8522824

ann-christin.roessler@imp.unierlangen.de

\section{Zusammenfassung \\ $\nabla$}

Ziel: In dieser Studie wurde ein Design für eine Patientenliege für Brust-Computertomografen hinsichtlich der Brustgewebeabdeckung und des Patientenkomforts optimiert. Zusätzlich wurden Nutzen und Akzeptanz einer Brustimmobilisierungsvorrichtung für das System evaluiert, welche mit Unterdruck arbeitet.

Material und Methoden: Die durchgeführte Studie bestand aus drei Studienteilen: In einer Positionierungsstudie wurden die Probandinnen auf einer Patientenliege mit austauschbaren Einsätzen im MRT untersucht, um die Gewebeabdeckung und den Komfort in verschiedenen Positionierungsvarianten zu bewerten. Dazu wurden unterschiedliche Liegeneinsätze mit verschiedenen Öffnungsdurchmessern und Formen (flach oder kegelförmig) genutzt. Zum Vergleich der Varianten wurden Brustlänge und Brustvolumen im effektiven Messfeld berechnet. Das Unterdrucksystem wurde auf einem stereotaktischen Biopsietisch, welcher die zukünftige Brust-CT-Liege darstellen sollte, auf Funktionalität und Komfort untersucht. Im letzten Studienteil wurde das Unterdrucksystem mithilfe von MRT-Aufnahmen hinsichtlich der Brustgewebeabdeckung bewertet.

Ergebnisse: Das beste Ergebnis hinsichtlich der Gewebeabdeckung wurde mit dem kegelförmigen Einsatz mit einem Durchmesser von $180 \mathrm{~mm}$ erreicht. Die flachen Einsätze konnten keine vollständige Abdeckung des Brustgewebes gewährleisten. Das Unterdrucksystem arbeitete zuverlässig und zog weiteres Brustgewebe ins effektive Messfeld. Der Komfort wurde für alle Einsätze mit gut bewertet; die beste Bewertung erzielten die kegelförmigen Einsätze.

Schlussfolgerung: Kegelförmige Liegeneinsätze scheinen für die Nutzung in Brust-CT-Systemen geeignet zu sein und eine nahezu vollständige Bildgebung der weiblichen Brust zu erlauben. Ein Unterdrucksystem scheint für eine Fixierung der

\section{Abstract \\ $\nabla$}

Purpose: The presented study aimed at optimizing a patient table design for breast CT (BCT) systems with respect to breast tissue coverage and patient comfort. Additionally, the benefits and acceptance of an immobilization device for BCT using underpressure were evaluated.

Materials and Methods: Three different study parts were carried out. In a positioning study women were investigated on an MRI tabletop with exchangeable inserts (flat and cone-shaped with different opening diameters) to evaluate their influence on breast coverage and patient comfort in various positioning alternatives. Breast length and volume were calculated to compare positioning modalities including various opening diameters and forms. In the second study part, an underpressure system was tested for its functionality and comfort on a stereotactic biopsy table mimicking a future CT scanner table. In the last study part, this system was tested regarding breast tissue coverage.

Results: Best results for breast tissue coverage were shown for cone-shaped table inserts with an opening of $180 \mathrm{~mm}$. Flat inserts did not provide complete coverage of breast tissue. The underpressure system showed robust function and tended to pull more breast tissue into the field of view. Patient comfort was rated good for all table inserts, with highest ratings for cone-shaped inserts.

Conclusion: Cone-shaped tabletops appeared to be adequate for $\mathrm{BCT}$ systems and to allow imaging of almost the complete breast. An underpressure system proved promising for the fixation of the breast during imaging and increased coverage. Patient comfort appears to be adequate.

Key points:

- Tissue coverage in breast CT is highly dependent on patient table design.

- An underpressure fixation system shows potential to increase breast coverage. 
Brust während der Bildgebung vielversprechend zu sein und erhöht zusätzlich die Gewebeabdeckung. Der Patientenkomfort scheint für ein zukünftiges BCT-System angemessen.

Kernaussagen:

- Die Gewebeabdeckung im Brust-CT hängt stark vom Patientenliegendesign ab.

- Ein Unterdruckimmobilisierungssystem ermöglicht eine erhöhte Brustgewebeabdeckung.

- Das vorgeschlagene Patientenliegendesign für Brust-Computertomografie vereint ausreichende Gewebeabdeckung mit hohem Patientenkomfort.
- The proposed breast CT patient table design combines good coverage and patient comfort.

Citation Format:

- Rößler AC, Wenkel E, Althoff F etal. The Influence of Patient Positioning in Breast CT on Breast Tissue Coverage and Patient Comfort. Fortschr Röntgenstr 2015; 187: 115-122

\section{Introduction}

$\nabla$

Breast cancer is the most frequent malignant solid tumor among women in industrial nations. In 2011 more than 230000 new breast cancers were detected in the US and approximately 40000 women died of this disease [1]. Since there is no adequate primary prevention of breast cancer, the detection of the disease at an early stage is the most important step to reduce mortality. According to Michaelson et al., the risk of dying in consequence of breast cancer increases by one percent with every millimeter of tumor size, so early detection increases the chance of survival significantly [2].

So far, mammography represents the established basis for early breast cancer detection examinations in screening programs [3]. Recently there have been developments in breast CT (BCT) systems that try to combine the advantages of X-ray-based mammography with full $3 \mathrm{D}$ imaging. Images acquired with BCT are free from superposition and can offer high resolution of better than $100 \mu \mathrm{m}$ at a dose level comparable to digital mammography and tomosynthesis [4]. Present systems examine the women lying prone on the patient table with one breast protruding through an aperture into the field of measurement [5-7]. The challenge in this setup is the complete coverage of the breast tissue, particularly of the tissue near the chest wall and the axillary tail [8]. A first design for a patient table for BCT was proposed in 1979 by GE when they introduced a prototype for dedicated breast imaging called CT/M. The table of this system was made of a flexible canvas material in the thorax region and could be tilted from a vertical to a horizontal position to facilitate the positioning of patients. This design made it difficult to examine the lower posterior aspect of the breast especially in women with a protuberant abdomen as well as the higher posterior aspect in women with severe kyphosis of the thoracic spine [9]. More than 20 years later, Boone et al. developed a patient table without tilting. The opening for the breast was in the middle of a table with a $5 \mathrm{~cm}$ depression in the central region of the tabletop. The idea was for women to "slump" into the opening to allow complete imaging of the breast up to the chest wall. The first clinical studies showed that the pectoralis as an indication for coverage of the posterior aspects of breast tissue was only identified in $18 \%$ of the breasts. Moreover, patients complained about an uncomfortable position due to a firm tabletop and a painful extension of the neck $[10,11]$.

Low patient comfort is also a problem of the BCT system of Ning et al. [8]. $43.5 \%$ of the women reported better comfort of BCT compared to mammography but only $4.3 \%$ felt no discomfort on the BCT examination table. CT images showed good coverage of posterior breast tissue but also artifacts in this area [8].
The study presented here aimed at providing input for designing a patient table for BCT offering optimal coverage of breast tissue and adequate comfort for patients. Several table designs differing in opening diameter and tabletop shape were tested in the first part of the study.

Due to the high resolution required for breast imaging, an immobilization device included in the tabletop may be advantageous to avoid a lack of sharpness as a result of even minute motion during image acquisition. Available BCT systems do not yet offer means for immobilization. Therefore, an immobilization device using underpressure was evaluated for efficiency and acceptance by patients in the second part of the study. Since this underpressure system may also be useful to pull more breast tissue into the field of view, a third part of the study was included to evaluate the effects of the underpressure system on breast coverage.

\section{Materials and Methods}

$\nabla$

The study was divided into three separate parts: 1 . positioning study evaluating different patient table systems; 2 . underpressure basic study testing the functionality and acceptance of an underpressure system; and 3. underpressure efficacy study assessing the effects of the underpressure system on breast coverage.

\section{A. Equipment}

\section{A.1. Positioning study}

MRI examinations were used to evaluate the effects of diverse patient positions and to visualize the different breast components. The experimental setup allowed objective evaluation of breast tissue coverage.

MRI measurements were performed on a 3.0 T Magnetom Verio System (Siemens Healthcare, Erlangen, Germany) using a T1weighted FLASH sequence. A dedicated 4-channel breast array coil (Noras Immobilization and Biopsy System; MR-BI230-PA, Höchberg, Germany) was used as the receiver coil. The acquisition time was set to $22 \mathrm{~s}$ to keep the whole examination short. 64 transverse slices with a thickness of $3 \mathrm{~mm}$ were acquired. The image matrix consisted of $220 \times 220$ pixels with a pixel size of $1 \mathrm{~mm} \times 1 \mathrm{~mm}$.

For patient positioning in the MRI system, a specially designed tabletop was used. It contained an aperture for different inserts in the breast region to test their effect on coverage. Acrylic glass was found to be an adequate material since it is easy to shape, contributes no signal to MRI and made patient positioning easier and reproducible due to its transparency. The inserts differed in opening diameter and general shape. Three flat and two coneshaped inserts whose opening diameters were related to the breast diameters determined in the work of Boone et al. were 
evaluated [12]. The depth of the cones was $32 \mathrm{~mm}$. The exact sizes of the inserts are specified in $\bullet$ Table 1, and the entire setting is shown in $\bullet$ Fig. 1. Three MRI markers (capsules containing glycerolnitrate) were attached to define the lower surface of the tabletop. Two foam wedge pillows were used for elevation of the contralateral side of the women.

\section{A.2. Underpressure basic study}

The underpressure system consisted of four different cups for different breast sizes made of a transparent plastic, a relative pressure sensor with a readout device, a manual pump, a back-pressure valve and connecting tubes. The cups with cup sizes A to D offered a silicone ring to seal it to the skin of the women ( $\bullet$ Fig. 2). With the help of the manual pump, the air inside the

Table 1 Tabletop inserts.

Tab. 1 Liegeneinsätze.

\begin{tabular}{|lll|}
\hline insert & shape & size of hole [mm] \\
\hline Flat S & Flat & 140 \\
\hline Flat M & Flat & 180 \\
\hline Flat L & Flat & 240 \\
\hline cone S & cone-shaped & 140 \\
\hline cone M & cone-shaped & 180 \\
\hline
\end{tabular}

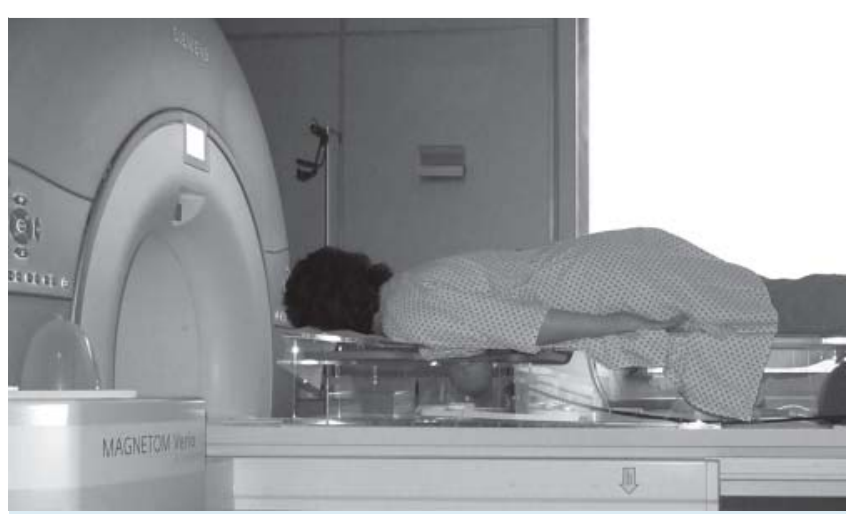

Fig. 1 MRI tabletop and measurement setting of the positioning study with the subject laying prone on the table with the left breast protruding freely into the opening.

Abb. 1 MRT-Liege und -Messverfahren der Positionierungsstudie: die Probandin liegt in Bauchlage, die linke Brust ragt frei durch die Liegenöffnung. cup was extracted so that the cup was fixed on the breast and dragged the breast tissue away from the breast wall into the field of view.

The basic functionality of the underpressure system was tested on a table for stereotactical breast interventions (MammoTest, Siemens Healthcare, Erlangen, Germany) which matches a typical breast CT scanner table. X-rays were not turned on. The underpressure cups were not integrated in the tabletop here, but placed manually at the torso.

\section{A.3. Underpressure efficacy study}

The underpressure system was also evaluated with the MRI setup to measure distance and volume of the breast in the field of view. For this purpose the underpressure system was integrated into the tabletop of the acrylic glass table.

\section{B. Subjects}

All women investigated via MRI signed the clinical information regarding MRI. They were aware that no diagnostic benefit would be drawn from the test results and gave written informed consent to the study. Women in the other study parts gave oral consent. No further ethics approval was required by the local ethics committee.

\section{B.1. Positioning study}

The positioning study was conducted from April to June 2012 at the University Hospital of Erlangen, Germany with 25 female volunteers. Women were excluded from the study if they had one or more contraindications for MRI such as cardiac pacemaker or claustrophobia and metallic implants with doubts regarding their MRI compatibility. Moreover, due to the design of the test setup, subjects with a body-mass index (BMI) of more than 30 were excluded.

\section{B.2. Underpressure basic study}

24 volunteers for this part of the study were recruited from the local diagnostic breast care unit of the University Hospital of Erlangen in May 2012 to test the basic functionality of the underpressure system at larger breast diameters. An exclusion criterion was a recent breast surgery at the investigated left breast.

\section{B.3. Underpressure efficacy study}

The underpressure efficacy study was conducted from April to June 2012. In this study part, 16 women volunteered to be investigated with the underpressure system in the MRI scanner to evaluate the effects on the coverage of the underpressure system.

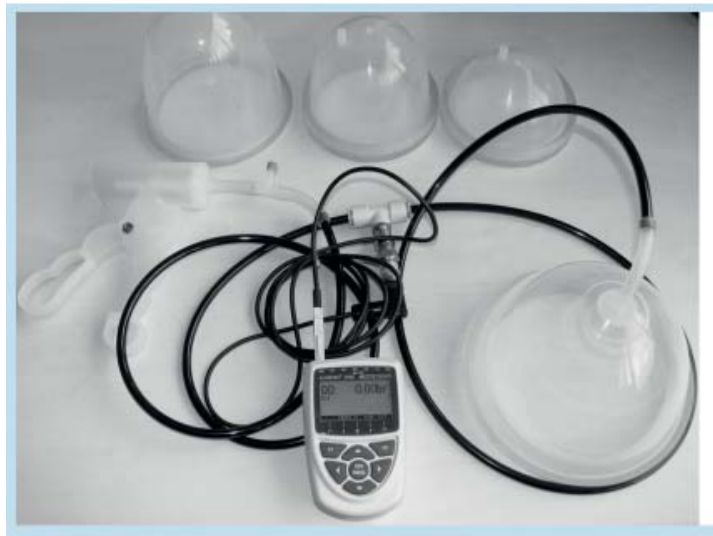

Cup sizes
\begin{tabular}{|c|c|c|}
\hline & diameter & length \\
\hline A & $110 \mathrm{~mm}$ & $70 \mathrm{~mm}$ \\
\hline B & $110 \mathrm{~mm}$ & $110 \mathrm{~mm}$ \\
\hline C & $135 \mathrm{~mm}$ & $130 \mathrm{~mm}$ \\
\hline D & $160 \mathrm{~mm}$ & $140 \mathrm{~mm}$ \\
\hline
\end{tabular}

Fig. 2 Left: underpressure system consisting of four different cups for diverse breast sizes made of a transparent plastic, a relative pressure sensor with a readout device, a manual pump, a back-pressure valve and connecting tubes. Right: Sizes of the underpressure cups $A$ to $D$.

Abb. 2 Links: das Unterdrucksystem bestehend aus vier verschiedenen Unterdruckschalen aus einem transparenten Kunststoff für unterschiedliche Brustgrößen, einem Drucksensor mit Auslesegerät, einer manuellen Pumpe, einem Rückschlagventil und Verbindungsschläuchen. Rechts: Größen der Unterdruckschalen von A bis D. 
Due to the design of the tabletop, only women with a breast diameter below $140 \mathrm{~mm}$ were included. Persons with contraindications for MRI were also excluded.

\section{Study workflow}

Basic data of the participants including age, body height and body mass were recorded. Over-bust and under-bust measurements were obtained with the help of a measuring tape. The difference between these two quantities defines the bra size based on the European standard system (DINEN 13402-3:2011). The left breast was used for all measurements. Breasts were classified by their outer shape as cone-shaped, cylindrical or pear-shaped.

\section{C.1. Positioning study}

For the positioning study 25 women were asked to position themselves on the patient table so that their left breast protruded freely through the opening in the table. Both arms lay next to the chest and the head was turned to the right.

The basic MRI images were acquired with the flat $\mathrm{L}$ insert to get a measurement of the complete freely protruding breast without the constrictions of a narrow insert in all participants. Then the measurement was repeated with the flat $S$ insert with and without a wedge pillow followed by the cone $\mathrm{S}$ and cone $\mathrm{M}$ inserts. The wedge pillows were put under the right shoulder and the right part of the pelvis of the women to test the effect of an elevation of the contralateral side on breast coverage. Women with large breasts (diameter $>140 \mathrm{~mm}$ ) were additionally investigated with the flat $\mathrm{M}$ insert (14 subjects). Inserts were changed after each image acquisition. Altogether up to 10 datasets were recorded for each subject.

Women were questioned about comfort during the procedure. For evaluation a grading system of 1 (very good), 2 (good), 3 (satisfactory), 4 (sufficient), 5 (poor) and 6 (insufficient) was used. Grades were given by the women after each positioning. In addition, they reported their points of discomfort.

\section{C.1.a. Image evaluation}

To view and evaluate data, the medical imaging software OsiriX [13] was used. The length and volume of the breast in the field of view were calculated with the help of the MRI markers which were positioned in the inserts and defined the lower surface of the tabletop. The length was defined as the distance from the markers to the nipple. The volume was defined as the complete breast tissue protruding in the field of view. For the basic data measurement with the flat L insert, all breast tissue up to chest wall was considered.

It will not be possible to extend the field of measurement directly under the tabletop in the future BCT system, because the installation of the X-ray tube and detector leaves a small gap for housing and insulation. This area illustrated in 0 Fig. 3 is considered in the study setup by shifting the field of measurement $22 \mathrm{~mm}$ down for all flat inserts, which was estimated based on commonly used components. This is not necessary for cone-shaped inserts since the X-ray tube and detector can be positioned around the cone.

Differences between the results for diverse inserts were calculated. Statistical calculations including testing for normal distribution and statistical significance (confidence interval: 95\%) were performed with Microsoft Excel and the Add-On WinSTAT.

In analogy to the work of O'Connell et al. [8], anatomical landmarks were examined to inspect the visible breast coverage. In the transverse and sagittal view, the points of inflection in the layer in which the nipple was visible were scanned. In addition, the presence of the pectoralis in the field of view was noted. Medial and lateral as well as superior and inferior landmarks were defined as the points of inflection of the breast tissue (॰ Fig.4).

\section{C.2. Underpressure basic study}

The primary purpose of the underpressure system is the fixation of the breast during measurements. To test this basic functionality, the cup size of the 24 women was calculated and the underpressure cup was adapted to the anatomical size. Subjects lying prone on the stereotactic biopsy table were investigated while their left breast protruded freely in the $240 \mathrm{~mm}$ wide opening of the table. The positioning of the arms and head was the same as in the positioning study. Cups were applied to the chest and underpressure was generated using a manual pump. In alternate order women started either by creating the underpressure themselves or it was done by the examiner. Thereafter the other mode was performed. Pumping was stopped when discomfort was reported by the women and the values of the final underpressure

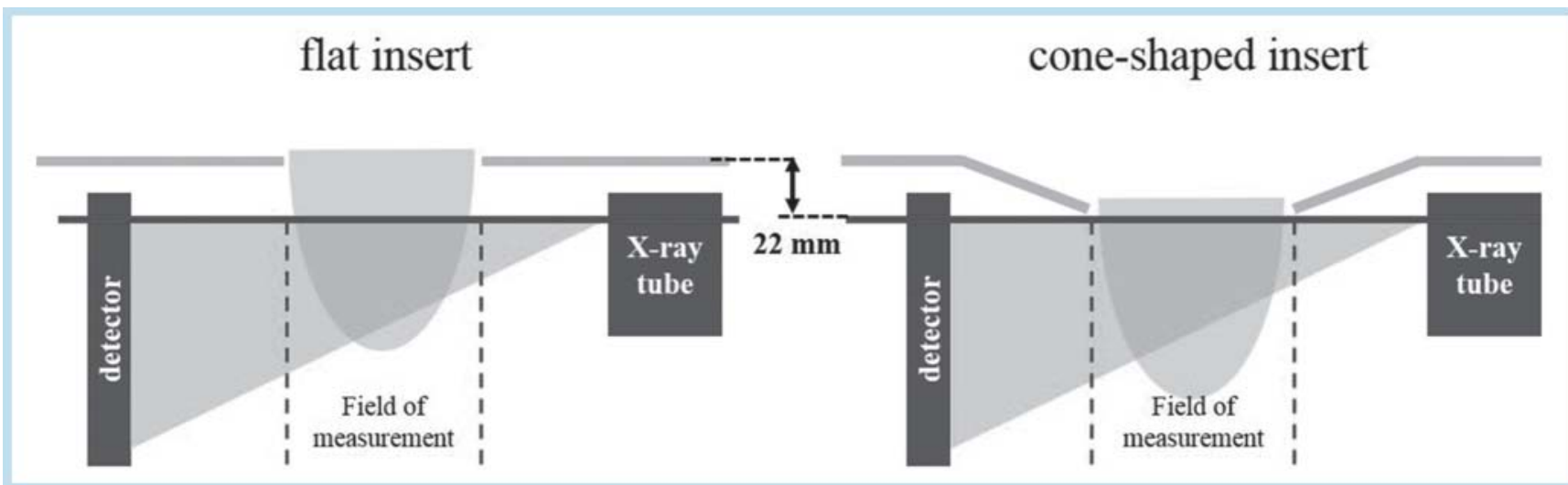

Fig. 3 Left: Field of measurement for flat inserts was shifted $22 \mathrm{~mm}$ down to simulate the position and dimension of the X-ray tube and detector in the future BCT system. Right: Field of measurement for cone-shaped inserts was located directly below the tabletop.

Abb. 3 Links: Das effektive Messfeld der flachen Einsätze wurde um 22 mm abgesenkt um die spätere Position und Größe der Röntgenröhre und des Detektors im Brust-CT-System zu simulieren. Rechts: Das effektive Messfeld der kegelförmigen Einsätze befand sich direkt unter der Liege. 


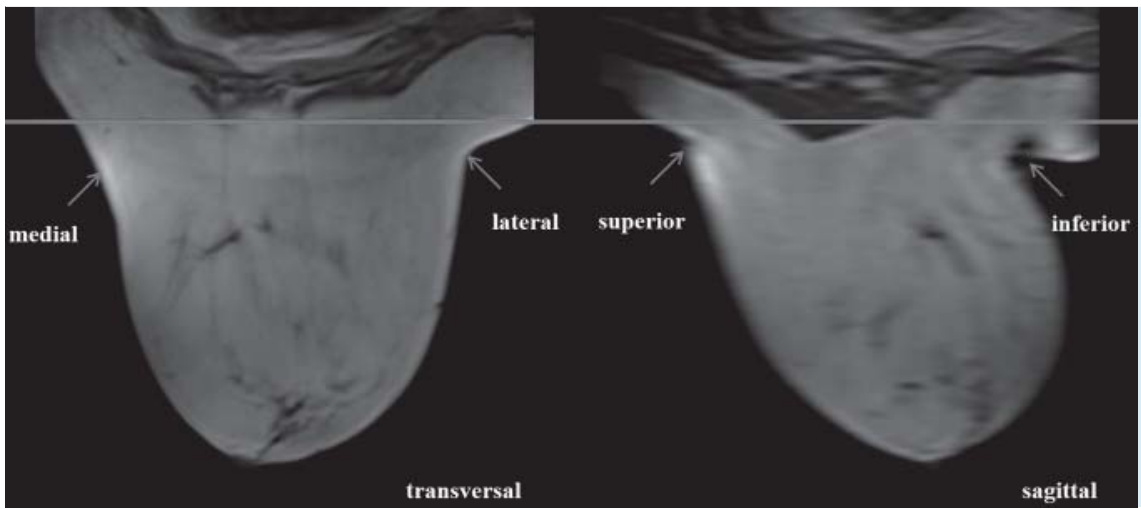

Fig. 4 Landmarks visible on MRI in transverse (left) and sagittal (right) views. The pectoral muscle is visible in the nipple layer of the sagittal view.

Abb. 4 Sichtbarkeit der Landmarken in der transversalen (links) und sagittalen (rechts) Ansicht. Der m.pectoralis ist in der mamillaren Schicht der sagittalen Ansicht sichtbar.

were recorded. To get a first impression of the effectiveness of the system, the area around the underpressure cup was marked with a cosmetic pencil with and without underpressure. To estimate the difference, a measuring tape was held next to the marks. Pictures were taken and analyzed with the freeware Gimp which offers means for receiving a true-to-scale measurement of distances in the resulting picture.

Test series at which no underpressure could be generated due to a leakage between the underpressure cup and the chest wall were recorded. After the investigation, women were asked about their comfort during the measurements. A scale from 1 (very good) to 6 (insufficient) was used. In addition, the women were asked whether they preferred to do the pumping themselves or have it done by the examiner.

\section{C.3. Underpressure efficacy study}

The underpressure system was tested for effects on breast coverage in 16 women using the flat S insert of the MRI tabletop and the C cup which fitted exactly in the opening. The cup was integrated into the tabletop and an underpressure of 150 mbar was generated. This value was derived from the first part of the underpressure study in which most subjects felt no major discomfort at this pressure. Instead of the MRI markers, the silicone rings of the cups were used as a reference so that differences in coverage with and without underpressure were determined by the distance from the silicone ring to the nipple.

\section{Results \\ $\nabla$}

\section{Positioning study}

The participants of the positioning study were aged between 19 and 75 years (mean: 47.6 years) with a BMI average of $22.7 \mathrm{~kg} / \mathrm{m}^{2}$ (range: 19.4 to $30.5 \mathrm{~kg} / \mathrm{m}^{2}$ ). Cup sizes calculated by under-bust and over-bust measurements are shown in 0 Table 2. Breasts were additionally classified by their outer shape as cone-shaped, cylindrical or pear-shaped. Most of the breasts were cone-shaped ( $44 \%, n=11)$ or cylindrical $(40 \%, n=10)$. Only $16 \%(n=4)$ were specified as pear-shaped.

Measurements with the flat L insert (diameter: $240 \mathrm{~mm}$ ) were used to receive basic data of the breasts. The lengths of the breasts ranged from 48 to $136 \mathrm{~mm}$ with a mean value of $79 \mathrm{~mm}$. The breast diameters in the transverse layer including the nipple were between 74 and $149 \mathrm{~mm}$ with a mean value of $106 \mathrm{~mm}$. The breast volumes ranged from 218 to $1320 \mathrm{ml}$ with a mean value of $293 \mathrm{ml}$.
Table 2 Cup sizes in different study parts.

Tab. 2 Körbchengrößen in den unterschiedlichen Studienteilen.

\begin{tabular}{lllll}
$\begin{array}{l}\text { cup size } \\
\text { (european } \\
\text { standard } \\
\text { system) }\end{array}$ & $\begin{array}{l}\text { difference } \\
\text { in over-bust } \\
\text { and under- } \\
\text { bust [cm] }\end{array}$ & $\begin{array}{l}\text { number of } \\
\text { subjects in } \\
\text { positioning } \\
\text { study }\end{array}$ & $\begin{array}{l}\text { number of } \\
\text { subjects in } \\
\text { underpressure } \\
\text { basic study }\end{array}$ & $\begin{array}{l}\text { number of } \\
\text { subjects in } \\
\text { underpressure } \\
\text { efficacy study }\end{array}$ \\
\hline <AA & $<10$ & 5 & 8 & 3 \\
\hline AA & $10-12$ & 5 & 5 & 4 \\
\hline A & $12-14$ & 7 & 4 & 5 \\
\hline B & $14-16$ & 4 & 3 & 2 \\
\hline C & $16-18$ & 3 & 3 & 1 \\
\hline D & $18-20$ & 1 & - & 1 \\
\hline E & $20-22$ & - & 1 & - \\
\hline
\end{tabular}

One woman measuring $<A A$ stated that she does not wear a bra.

Eine der untersuchten Frauen mit einer Körbchengröße $<\mathrm{AA}$ gab an, keinen $\mathrm{BH}$ zu tragen.

The influence of a cone lowering of $32 \mathrm{~mm}$ in the patient table was evaluated with the cone $\mathrm{S}$ and cone $\mathrm{M}$ insert and compared to the flat $\mathrm{S}$ and flat $\mathrm{M}$ insert. Both datasets showed a significant $(p<0.05)$ shift in breast volume into the field of view. The mean breast volume value increased by $300 \mathrm{ml}$ for the small insert and by $351 \mathrm{ml}$ for the medium insert. The length of the breast in the field of view increased by $30 \mathrm{~mm}$ (flat S-cone S) and $26 \mathrm{~mm}$ (flat M-cone M). These differences were statistically significant $(\mathrm{p}<0.05)$ ( $\bullet$ Table 3$)$.

To evaluate the influence of the diameter of the opening in the table, the flat $\mathrm{S}$ and flat $\mathrm{M}$ insert and the cone $\mathrm{S}$ and cone $\mathrm{M}$ insert were compared. A bigger opening diameter led to an increase in breast tissue in the field of view for both types of insert. With flat inserts a difference of $7 \mathrm{~mm}$ in length and $54 \mathrm{ml}$ in volume in favor of the flat M insert was found. With the cone-shaped inserts the difference was $5 \mathrm{~mm}$ in length and $122 \mathrm{ml}$ in volume in favor of the cone M insert ( $\bullet$ Table 3 ).

Finally the influence of the wedge pillows was analyzed. The elevation of the contralateral side showed only a very small, but not significant, improvement both for the flat and for the coneshaped inserts ( $\bullet$ Table 3 ).

In the patient comfort study the women stayed in each position for about $5 \mathrm{~min}$. The cone-shaped inserts were rated with an average of 1.8 , and therefore were significantly superior $(p<0.05)$ to the flat inserts with an average of 2.3. The wedge pillows improved the comfort for flat inserts, but reduced it for cone-shaped inserts. An increase in the opening diameter showed no significant difference. 
Table 3 Differences in positioning alternatives.

Tab. 3 Unterschiede zwischen den Lagerungsalternativen.

\begin{tabular}{|c|c|c|c|}
\hline \multicolumn{4}{|c|}{ influence of cone-shaped inserts compared to flat inserts } \\
\hline $\begin{array}{l}\text { number of } \\
\text { subjects }\end{array}$ & insert & $\begin{array}{l}\text { breast length } \\
{[\mathrm{mm}]}\end{array}$ & $\begin{array}{l}\text { breast volume } \\
{[\mathrm{ml}]}\end{array}$ \\
\hline \multirow[t]{3}{*}{25} & flat $S$ & $48 \pm 21$ & $237 \pm 194$ \\
\hline & cone S & $78 \pm 20$ & $537 \pm 224$ \\
\hline & difference & $30 \pm 6(p<0.05)$ & $\begin{array}{l}300 \pm 80 \\
(p<0.05)\end{array}$ \\
\hline \multirow[t]{3}{*}{14} & flat M & $57 \pm 26$ & $331 \pm 274$ \\
\hline & cone $\mathrm{M}$ & $83 \pm 25$ & $682 \pm 313$ \\
\hline & difference & $26 \pm 4(p<0.05)$ & $\begin{array}{l}351 \pm 89 \\
(p<0.05)\end{array}$ \\
\hline \multicolumn{4}{|c|}{ influence of insert diameter } \\
\hline $\begin{array}{l}\text { number of } \\
\text { subjects }\end{array}$ & insert & $\begin{array}{l}\text { breast length } \\
\text { [mm] }\end{array}$ & $\begin{array}{l}\text { breast volume } \\
\text { [ml] }\end{array}$ \\
\hline \multirow[t]{3}{*}{14} & flat S & $50 \pm 23$ & $278 \pm 234$ \\
\hline & flat M & $57 \pm 26$ & $331 \pm 274$ \\
\hline & difference & $7 \pm 7(p<0.05)$ & $54 \pm 71(p<0.05)$ \\
\hline \multirow[t]{3}{*}{14} & cone S & $78 \pm 23$ & $560 \pm 272$ \\
\hline & cone M & $83 \pm 25$ & $682 \pm 313$ \\
\hline & difference & $5 \pm 4(p<0.05)$ & $\begin{array}{l}122 \pm 64 \\
(p<0.05)\end{array}$ \\
\hline \multicolumn{4}{|c|}{ influence of wedge pillows } \\
\hline $\begin{array}{l}\text { number of } \\
\text { subjects }\end{array}$ & insert & $\begin{array}{l}\text { breast length } \\
{[\mathrm{mm}]}\end{array}$ & $\begin{array}{l}\text { breast volume } \\
{[\mathrm{ml}]}\end{array}$ \\
\hline \multirow[t]{3}{*}{$24^{1}$} & flat S & $49 \pm 21$ & $238 \pm 198$ \\
\hline & flat S with pillows & $50 \pm 20$ & $245 \pm 206$ \\
\hline & difference & $2 \pm 8(p=0.3)$ & $7 \pm 51(p=0.5)$ \\
\hline \multirow[t]{3}{*}{25} & cone $\mathrm{M}$ & $78 \pm 20$ & $537 \pm 224$ \\
\hline & cone $\mathrm{M}$ with pillows & $79 \pm 19$ & $552 \pm 230$ \\
\hline & difference & $1 \pm 6(p=0.3)$ & $15 \pm 60(p=0.1)$ \\
\hline
\end{tabular}

${ }^{1}$ One of the datasets for the flat $\mathrm{S}$ insert was not analyzable due to technical difficulties.

Points of discomfort were recorded for 25 subjects during 128 measurements. Most subjects complained about pain in the shoulders ( 7 subjects), ribs ( 6 subjects) and sternum ( 5 subjects) due to the uncushioned tabletop and the border of the opening. Two subjects complained about pain in the hips, one about overstretching of the neck because of the positioning of the head and one about pain in the knees. Pain in the shoulders appeared most frequent for the cone-shaped inserts with wedge pillows, whereas pain in the ribs and sternum were caused by the use of flat inserts.

We also recorded the visibility of landmarks to allow a comparison to previous studies. The results are shown in 0 Table 4. The best-rated insert (cone $\mathrm{M}$ ) showed superior coverage in length and volume. 14 subjects were evaluated with this insert. $100 \%$ of inferior and $93 \%$ of superior landmarks were detected. Lower detection rates were recorded for medial landmarks (86\%) and lateral landmarks (79\%). The pectoralis indicating the posterior coverage was visible in $93 \%$ of the exams in the range.

\section{Underpressure basic study}

24 participants with a mean age of 54 years (range 20 to 83 years) and with an average BMI of 24.0 (range: 18.0 to $38.1 \mathrm{~kg} / \mathrm{m}^{2}$ ) were examined. The over-bust measurements ranged from 89 to $124 \mathrm{~cm}$, the under-bust from 71 to $104 \mathrm{~cm}$. The underpressure cups used were selected according to the calculated cup size (refer to $\bullet$ Table 2).
Table 4 Visibility of landmarks.

Tab. 4 Sichtbarkeit der Landmarken.

\begin{tabular}{|llclll|} 
landmark & superior & inferior & medial & lateral & posterior \\
\hline $\begin{array}{l}\text { number } \\
(\mathrm{n}=14)\end{array}$ & 13 & 14 & 12 & 11 & 13 \\
\hline percentage & 93 & 100 & 86 & 79 & 93
\end{tabular}

The system worked reliably in $85 \%$ of the tests. Difficulties showed up for women with small under-bust measurements due to the relatively high rigidity of the underpressure cups and a subsequent leakage of the system.

Underpressure values were recorded with a mean of 142 mbar when subjects generated the underpressure themselves and 125 mbar when the underpressure was built up by the examiner. Comfort evaluation showed that the generation of underpressure by the examiner was favored by $29 \%$ of the women, $14 \%$ preferred to generate the underpressure themselves and 57\% saw no difference in the two approaches. The overall comfort was rated with a mean value of 2.2

The effects on breast coverage were evaluated for all datasets when the examiner generated the underpressure. Since not all previously defined landmarks could be seen in the photographs, some of them had to be excluded from the measurements. The inferior landmark was visible only in $18 \%$ of the datasets, and the medial landmark in 55\%. Superior, lateral and axillary landmarks were seen in $90 \%$ of the images. For all landmarks a shift of breast tissue into the cup was clearly visible ( $\bullet$ Fig.5).

\section{Underpressure efficacy study}

The participants in this study part were aged 19 to 75 years (mean: 42.5 years) with a BMI of 19.4 to $26.6 \mathrm{~kg} / \mathrm{m}^{2}$ (mean: $22.1 \mathrm{~kg} / \mathrm{m}^{2}$ ). Under-bust measurements ranged from 74 to $84 \mathrm{~cm}$ (mean: 78.5) and over-bust measurements from 80 to $98 \mathrm{~cm}$ (mean: 90.3). Cup sizes are shown in $\bullet$ Table 2.

This study part conducted on the MRI system showed a clear effect of underpressure on breast coverage. In 3 women the underpressure system leaked, so that only datasets of 13 women were evaluated. Differences in breast length (mean: $6.0 \pm 5 \mathrm{~mm}$ ) and volume (mean: $119.0 \pm 63 \mathrm{ml}$ ) in the field of view were significant $(\mathrm{p}<0.05)$. The anterior edge of the pectoralis muscle was examined to determine the shift of breast tissue into the field of view. It was shifted by a mean of $9 \mathrm{~mm}$ and thereby significantly $(\mathrm{p}<0.05)$. An example of this is shown in $\bullet$ Fig. 6.

Comfort evaluation in the MRI system with the underpressure system was rated with an average of 3.4 and was thereby worse than all other positioning alternatives.

\section{Discussion}

\section{Positioning study}

The study showed that the modified shape of the patient tabletop from flat to cone-shaped measurement aperture resulted in significantly improved coverage of breast tissue in the field of view of the BCT system. On average, the measured breast length and volume increased by $30 \mathrm{~mm}$ and $300 \mathrm{ml}$, respectively, for the small inserts and $26 \mathrm{~mm}$ and $351 \mathrm{ml}$, respectively, for the medium inserts. An increase of the opening diameter of the tabletop apparently caused an average stretching of the breast tissue from the chest 


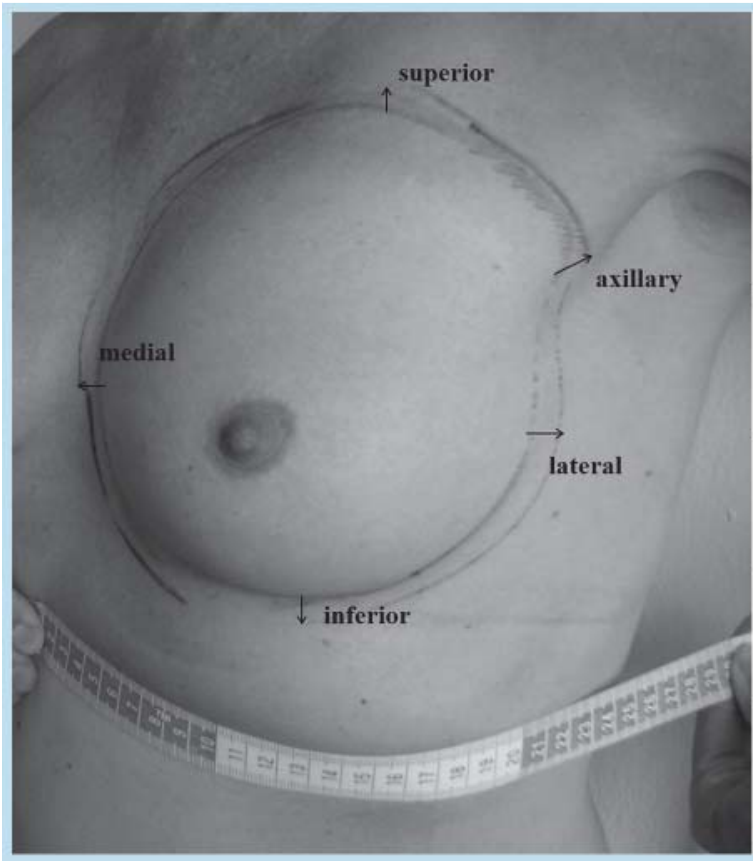

\begin{tabular}{|c|c|}
\hline Landmark & $\begin{array}{c}\text { Mean } \\
\text { difference }\end{array}$ \\
\hline Superior & $10.0 \mathrm{~mm}$ \\
\hline Inferior & $4.0 \mathrm{~mm}$ \\
\hline Medial & $9.0 \mathrm{~mm}$ \\
\hline Lateral & $12.0 \mathrm{~mm}$ \\
\hline Axillary & $14.0 \mathrm{~mm}$ \\
\hline
\end{tabular}

Fig. 5 Definition of landmarks and differences without and with underpressure in the study on the stereotactic biopsy table.

Abb.5 Definition der Landmarken mit und ohne Unterdruck in der Studie auf dem stereotaktischen Biopsietisch.

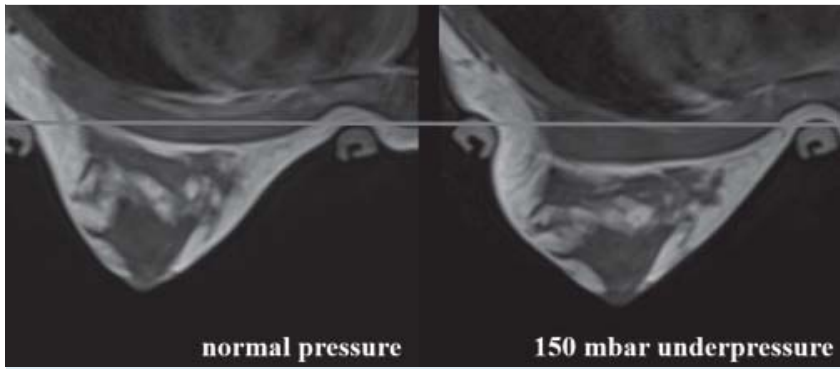

Fig. 6 24-year-old woman in positioning study with a clearly visible shift of the breast tissue into the field of view due to underpressure.

Abb. 6 24-jährige Frau in der Positionierungsstudie mit einer klar sichtbaren Verschiebung des Brustgewebes in das effektive Messfeld durch den verwendeten Unterdruck.

wall into the field of view of $7 \mathrm{~mm}$ in length and $54 \mathrm{ml}$ in volume for the flat inserts and $5 \mathrm{~mm}$ and $122 \mathrm{ml}$ for the cone-shaped inserts. Significantly better results with the medium and large inserts were consistently observed. The contralateral elevation of the women with the help of the wedge pillows brought no clear advantages. There was a slight improvement especially in the axillary region for some women but for others the pillows had the negative effect of elevation of the medial part of the breast. The visibility of landmarks at an average of $90 \%$ of the investigated cases was good and thereby comparable to the results of O'Connel et al. [8]. This percentage was increased by the use of an underpressure immobilization device. Overall, a patient table design with a cone $\mathrm{M}$ insert appears most promising.

Comfort was best for the cone $\mathrm{M}$ insert with an average rating of 1.8. Points of discomfort resulted mostly from the hard acrylic glass tabletop used for the positioning study. The edges of the unpadded surfaces produced marks on the shoulders and thorax during the long acquisition time needed for all positioning alternatives. In the planned BCT system, standard datasets will be acquired in less than $10 \mathrm{~s}$. Pain occurring due to longer positioning on one body side will likely be reduced since adequate padding of the tabletop for a final design is expected. It can be assumed that circumstances like the narrowness and noisiness of the MRI system negatively influenced the comfort of the subjects. Relaxed positioning of the women during image acquisition is likely to prevent movement of the women and thereby limit motion and effects on image quality.

The present study was conducted with a relatively small number of subjects. Due to the restricted geometry of the MRI system combined with the tabletop upon the original patient table of the MRI system, women with a BMI smaller than $30 \mathrm{~kg} / \mathrm{m}^{2}$ were chosen to ensure their fitting into the MRI bore. Because of these restrictions, the average BMI $\left(\mathrm{BMI}=22.7 \mathrm{~kg} / \mathrm{m}^{2}\right)$ was lower than the average of the population in Germany $\left(\mathrm{BMI}=24.9 \mathrm{~kg} / \mathrm{m}^{2}\right)$ [14].

\section{Underpressure basic study}

Since we did not apply restrictions for BMI or breast size in this study part, the mean basic data values were significantly higher than in the positioning study. With $118 \mathrm{~mm}$ the mean breast diameter was $12 \mathrm{~mm}$ larger and therefore closer to the German average. Cup sizes also differed significantly. The subject group for the underpressure study seemed to be more representative for the total population ( Table 2 ).

Problems occurred with respect to the identification of inferior and medial landmarks. These were caused by the design of the patient table for biopsy. The biopsy system underneath the table made it difficult to reach the breast for marking. This issue can be resolved when a dedicated patient table for BCT is built.

The functionality of $85 \%$ for the underpressure system can be rated as good considering the fact that the cups were not yet specially designed for this application but for use in an upright position. Leakages occurred next to the sternum or at the lateral chest wall especially when subjects contracted their pectoralis due to a specific positioning, e.g. elevation of the contralateral body side. A slightly different shape of the cups or a softer seal ring should reduce or solve this problem. The effects of the underpressure system on breast tissue coverage appear promising. If higher reliability cannot be achieved, another method for immobilization should be considered. The effect of underpressure on regular 
breast tissue and cancer has not been investigated. Underpressure might influence the behavior of enhancement in contrastenhanced CT which may become a subject of future investigation in further studies.

The comfort of the underpressure system was rated "good". No patient reported strong discomfort during investigation. The approach appears to offer potential for the use in a BCT system.

\section{Underpressure efficacy study}

The functionality of the underpressure system included loosely into the tabletop reached a value of $81.0 \%$ which is less than in the stereotaxis table. For further development the underpressure system should be integrated permanently into the tabletop to fixate the breast during image acquisition. Patient comfort was rated lower compared to the other positioning alternatives. With a softer sealing ring and reduced underpressure, patient comfort might be increased further.

The effects of the underpressure system on breast tissue coverage were promising. For all assessed patients breast length and volume increased. Follow-up studies should include a direct comparison between images with and without underpressure, for example by use of dynamic MRI sequences and image subtraction to evaluate the effect on immobilization.

The development of the final patient table should reflect the findings of this study with respect to table shape and opening diameter. A cone-shaped insert with an opening of at least $180 \mathrm{~mm}$ should be provided. In any case, new designs for underpressure cups are indicated. Other methods for breast immobilization would be of interest. In further patient positioning studies, a higher number of subjects should be evaluated and influences of respiration and other cup sizes should be tested.

\section{Clinical relevance}

- The patient table design was evaluated and found appropriate for a breast CT system.

- The opening diameter and design of the patient table for a breast CT system have a considerable influence on the amount of breast tissue in the presumed scan field of view.

- The fixation of the breast with an underpressure system appeared to be a good approach to increase breast coverage.

- Patient comfort was rated well during image acquisition with the breast CT system.

\section{References}

1 American Cancer Society. Breast Cancer: Facts \& Figures. [ACS Web site]. 2011-2012. Gefunden unter: http://www.cancer.org/acs/ groups/content/@epidemiologysurveilance/documents/document/ acspc-030975.pdf am June 26, 2013.

2 Michaelson JS, Silverstein M, Sgroi $D$ et al. The effect of tumor size and lymph node status on breast carcinoma lethality. Cancer 2003; 98 : 2133-2143

3 Petitti DB, Calonge N, Lefevre ML et al. Breast Cancer Screening: From Science to recommendation. Radiology 2010; 256: 8-14

4 Kalender WA, Beister M, Boone JM et al. High-resolution spiral CT of the breast at very low dose: concept and feasibility considerations. European radiology 2012; 22: $1-8$

5 Boone JM, Nelson TR, Lindfors KK et al. Dedicated Breast CT: Radiation Dose and Image Quality Evaluation. Medical Physics 2001; 221: 657 667

6 Ning R. Evaluation of flat panel detector cone beam CT breast imaging with different sizes of breast phantoms. Proc. of SPIE 2005; 5745: 626-636

7 Crotty DJ, Madhav P, Mckinley RL et al. Investigating novel patient bed designs for use in a hybrid dual modality dedicated 3D breast imaging system. Proc. of SPIE 2007; 6510: 65101H-65101H-65110

8 O'connell A, Conover DL, Zhang Y et al. Cone-beam CT for breast imaging: Radiation dose, breast coverage, and image quality. Am J Roentgenol 2010; 195: 496-509

9 Chang CHJ, Sibala JL, Fritz SL et al. Computed Tomography in Detection and Diagnosis of Breast Cancer. Cancer 1980; 46: 939-946

10 Boone JM, Kwan AL, Yang $K$ et al. Computed tomography for imaging the breast. Journal of mammary gland biology and neoplasia 2006; 11: $103-111$

11 Lindfors KK, Boone JM, Nelson TR et al. Dedicated Breast CT: Initial Clinical Experience. Radiology 2008; 246: 725 - 733

12 Boone JM, Shah N, Nelson TR. A comprehensive analysis of DgN[sub CT] coefficients for pendant-geometry cone-beam breast computed tomography. Medical Physics 2004; 31: 226

13 Rosset A, Spadola L, Ratib O. OsiriX: an open-source software for navigating in multidimensional DICOM images. Journal of digital imaging 2004; 17: 205-216

14 Statistisches Bundesamt. Gesundheitsrelevantes Verhalten: Körpermaße nach Altersgruppen; 2009, Gefunden unter: https://www. destatis.de/DE/ZahlenFakten/GesellschaftStaat/Gesundheit/ GesundheitszustandRelevantesVerhalten/Tabellen/Koerpermasse. html am 26 June, 2013 